\title{
Rethinking of user studies in academic libraries in the context of paradigm shift due to ICT
}

\section{R. Pandian ${ }^{1}$, G. Krishnamoorthy ${ }^{1}$ and K. Kaliyaperumal ${ }^{2}$ \\ ${ }^{1}$ Anna Univ. Library, Anna Univ. ${ }^{2}$ Univ. of Madras, Chennai-600 025, India}

pandi1958@gmail.com, kkperumal3@gmail.com

Abstract: The modern libraries are equipped with latest technological developments ranging from digital archives, repositories, delivery of the net contents and providing seamless global access to the digital information resources. This paper focuses on the importance of library user studies and stresses the required methodological procedures.

Keywords: Digital library, ICT, users. Introduction

The academic libraries are the backbone of formal/ informal education of a society ranging from schools to University. These libraries are important supplemental to the education system of a country. For instance, accreditation or for recognizing an institution, the higher education body of India (UGC/AICTE) adheres greater importance to library facility of an institution. The level of literacy rate in a country is also weighed from available academic library facilities and services in the educational system.

\section{Paradigm shift in the usage of academic libraries}

Even before World War II, librarians had experimented with punch card systems for various library operations (Biswas Subhas,1985-86). In 1970s they began to explore the use of machines like IBM 1401 for batch processing of some of the library functions. Late in that decade, microcomputers were introduced in business and industry. Because of the multi-task capacity of those machines, the libraries were benefited for information processing in multiuser environment. Now, the information communication technology (ICT) has changed many aspects in the library especially in special and academic Libraries.

Mini-micro computer systems and related software made it attractive for vendors to develop and market library software for use, which paved way for academic library automation at many libraries. In the mid 1980s most library automation literature focused on these mini-micro computer applications, the emerging standards like MARC, CCF, Z39.5, etc., and access to bibliographic information through bibliographic utilities (OCLC, RLIN, WLN). An information exchange between libraries, sources and end users expanded the demand for standards for communication of bibliographic information and easier ways to accomplish these tasks increased (Francher Beeler, 1974). As costs for computer hardware and peripherals came down, it became financially feasible for even smaller academic libraries to think of automating their library functions.

Many operating systems, utility programs, a variety of display, storage and communication devices have emerged and begun to integrate around the desktop platform. CDROM, video-discs, graphic display interfaces, integration of text, multimedia, scanning devices, non-key board input devices etc., appeared on the desktop. In 1990s smaller academic libraries can automate at least some of their library functions (Guide, 1984).

From early 1990s, the concept of networking emerged as a strong support for information communication and exchange. Optical and digital technology (Gupta Anuradha,1987) made it possible to produce digitized materials of local origin. This trend complemented the ever growing e-publishing industry in production and delivery of eresources. Now the concept of 'hybrid library' is well received and practiced.

Two decades ago, experts in the information field had forecasted that, "towards the end of the last century we may be able to browse information electronically in a remote library offering electronic browsing and "tele-delivery". But today, it has become reality. Currently our libraries are equipped with all hardware, software and related accessories with respect to ICT (Gupta Anuradha 1973; Guern, 1990, Lynden, 1990; Ikeuchi, 1999) applications for library and its use. The academic libraries are holding materials in digitized form and its users communicate with it over a telephone link or a co-axial or fiber optic cable. Its purpose is to supply its users with copies of textual, audio or video material on request. In libraries, several ICT based services are developed to help users search for their information. Book lending through computer terminals, catalogue search via OPAC (Online Public Access Catalogue) terminals, book reservation, books on CDs are some of the computer based information services offered. Online search of abstracts and indexes, CD search etc., are some other services the academic libraries are offering today.

e-Journal Consortium is the order of the day. The ejournals are passed on to users through dedicated networks. e-Theses, e-books, e-prints, e-databases, e-institutional repositories, e-heritage materials are some more digital information available in to-days' libraries. In total the current scenario of ICT environment of libraries enhances the existing print based library system into 'hybrid library system', which creates more expectations from users' point of view of information search and retrieval. To cater to the needs of the academic library system, two e- journal consortia have been established in India viz. UGC- Infonet Consortia and INDEST Consortia. All these developments are focusing on the changing phases of academic library systems. In this context it is necessary to study the end users acceptance of the new library environment. Thus the user studies are inevitable phenomena in the libraries.

\section{Status of user studies}

The user studies are carried out basically for the purpose to find out the difficulties experienced by the users while using the library resources, services and what they expect from the libraries. Studies of information seeking behavior are mostly based on questionnaire method supplemented by an interview. The users are prime concern of a library. The academic library has been established to serve to the educated society and it present growth start from store house to virtual information center. The information seeking behaviors (Wood, 1969) of the library users (belonging to any discipline) may be stated as follows:

1. The role of user is an important determinant of information need.

2. Accessibility is a key factor determining the use of an information sources.
Sci. Technol. Edu

CIndian Society for Education and Environment (iSee)
"ICT-driven academic libraries" http://www.indjst.org
Pandian et al. Indian J.Sci.Technol. 
3. The user's awareness of, and ability to use, an information source is often imperfect.

4. Interpersonal communication is one of the most important means of transmitting information.

5. The amount of information required varies considerably between persons.

6. Users often require information to be supplied at short notice; decisions may have to be at a given time regardless of the availability of information.

Role of librarians in the changing scenario

A good library system should have an efficient and talented librarian with the following pre-requisites:

1. Thoroughly knowledge on library users to design, develop, organise, and operate the library system giving emphasis on mutual feedback between users and library professionals wherever necessary.

2. Users must always be informed as how to use the facility.

The first prescription calls for "user study" and the second "user education". Obviously, their relationship is very intimate; and their significance is very high in relation to a library system.

The users form an integral part of the library system. They are the final link in the information transfer chain. All professional activities in a library, and every bit of money spent for these activities are all for the users of information. If the users cannot find the information they need, or does not know how to find relevant information available to them, the library system falls short of its ultimate goal. Thus, the users occupy the central place in every library.

The nature of user studies

To understand the user and their information behaviour, user studies are conducted. User studies are concerned with the following aspects:

1. The nature of their appreciation about the role of information in carrying out their responsibilities and duties;

2. The extent of their knowledge or ignorance about the pertinent sources of information needed by them;

3. The nature of their information seeking behaviour;

4. The nature of their reaction to information services, and to professional tools, techniques, and methods;

5. The nature of their information need in terms of various relevant factors.

Rethinking of user studies in academic libraries

In the broader terms, the academic researcher wants to pursue literature and other type of information regardless of their geographic location, physical medium and format, or language form. The researcher wants to move electronically to the information and draw it out of databases, using natural language and without particular attention to the logic of the system he or she is accessing. The researcher wants to probe information at the chapter or the paragraph level and to look at specific tables, charts, illustrations, and other graphic and pictorial matter. So there is an open challenge for libraries to learn and use expert systems and work with ICT environment. When useful material is found, that researcher will want, through expert system, electronic word processing, to download, to cut it out, move it over, and paste that information into a personal file (Vijayalaxmi \& Maheswarappa, 2001).

\section{Vol.2 No.10 (Oct 2009)}

ISSN: 0974- 6846
A researcher having difficulty finding what he or she needs will want both computer-based assistance and faceto-face contact with experts. The matter of freedom of choice is very important to scholars.

At the press of a button, the researcher expected to see the text of references cited in the work he or she is reading, to be able to go deeper into the references cited in secondand-higher-level sources in the literature, and to engage in an interactive form of citation analysis. Also the researcher may want to ask for an explanation of a topic or concept, perhaps indicating to the system his or her level of expertise in the subject area.

When the researcher has gathered the needed information, he or she will build a file based on personalized, idiosyncratic logic. They may prepare an article for electronic publication. The system should support these activities.

Users want to read books while sitting comfortably in an armchair, in bed, while eating their lunch, or in the train, so text materials would usually be delivered to a smart card or whatever storage device was used with an electronic book reader.

As users' time in library is expected to go high with computer usage, the need for ergonomic seating and optical screen is paramount importance. Equally challenging is to protect the online information and users from viruses and spam.

The inability of academic libraries to offer the collections their users' desire has become more pronounced each year. In response, libraries have moved in two directions: the rapidly growing consortium movement and the movement to advocate and support reforms in scholarly communication.

Consortia are regarded as an effective strategy to offer libraries the ability to give users the access they are coming to expect and demand to a much broader range of materials than any one library could possibly offer.

Reforms in the system of scholarly communication are seen as the most critical piece as the long-term solution to return the ownership and control of our research output to our research institutions or to publishers who are willing to contribute valuable services for a reasonable rate of return.

The prototype of yesterday's academic librarian is today's endangered species. As end users become more and more proficient in researching their own answers, the librarian is transformed in to an information technician who propels that user towards the discovery of information sources. The librarian must serve as the specialist, the promoter, the interpreter, the disseminator, and the trainer (Ashu Shokeen \& Sanjay K. Kausrila, 2002).

Not only must we become proficient at information retrieval through automation, but we must also learn to interact with MIS departments, human resources, and communication services. Only then can we become a vital part of the corps of decision-makers. We must be confident in our ability to have ICT applications to our advantage in providing more information in less time at a cheaper cost, and to have the mental toughness to adapt to new ideas. The information professionals of the future will form the paradigm of information use and retrieval through the intricate network of computers, information technology, and communication. Today's librarian must make the users
Sci. Technol. Edu

CIndian Society for Education and Environment (iSee)
"ICT-driven academic libraries" http://www.indjst.org
Pandian et al. Indian J.Sci.Technol. 
aware of new developments in the world of information and should carry the promotion to the highest reaches of the institution.

End-users need librarians (Spink et al., 2002) to show them concepts that relate to the efficiency of the research; industry and academia need librarians to disseminate knowledge; administrators need librarians to interpret technology. In this context, it is essential to rethink the existing pattern of user studies in the libraries. Perhaps most of the libraries are using either questionnaire or interview methods. These methods are suitable only for the traditional library systems. But changing nature of the library system wants the following modes of user studies:

$\checkmark$ Rethinking of improved methods of transactional log analysis for assessing the user expectations

$\checkmark \quad$ Introducing computer based simulations to assess the use pattern of e-resources and digital archives

$\checkmark$ Use of Fuzzy logic so as to measure the performance of the digital system for delivering or retrieving the required information by the users.

$\checkmark$ Time log analysis to assess the speed of accessing particular information by a particular reader or users.

\section{Scope of libraries for future needs}

The emergence of learning society demands information for all aspects of life. Timely information is needed for decision making for social scientists and politicians. But the present library system is not capable of meeting such needs. The great majority of our people are illiterate. Nation-wide public library system is to be developed all over India so that those people who quench the intellectual hunger will have access to information sources. Information will be valued in future whatever nomenclature is given whether it be 'Information Age', 'Paperless society' or 'Post Industrial society'. Alwin Toffler is of the opinion that society is moving to 'Electronic cottage' or 'Information literate society'. International competition and high technology terrorism will affect the society in general. Lancaster predicted a 'Paperless Information Society' by 2000 AD. Whereas Likert in 'Pathways of Communication' stresses on the importance of printed media. Those advocating changes in society are optimistic that communication technology can be used for well-informed citizenship and national. Hence, the libraries are characterized as "social institutions" and "centre for learning" of the society. India has rich social customs and heritage but needs well-developed public or academic library system for promoting $R \& D$ and cultural value.

Conclusion

Academic libraries play an important role for independent life long learning of individuals in a society. They are the centres of all educational activities in formal education system where the role of librarian is so vital. So, it is necessary that every library should be well equipped in terms of resources which have to be organized properly to provide effective library services to the academic society. Library professionals in the educational process are to inculcate learning, reading habits and educational development of the student. Unfortunately, in India, the library system is not well recognized, lack of literature, proper space, furniture, audiovisual materials, etc. These conditions are much worse as far as public libraries are
Vol.2 No.10 (Oct 2009)

ISSN: 0974- 6846 concerned. The significance and potential of the public library are yet to be realized fully. Woefully, studies on public library systems have largely been absent in the curriculum of Indian library science schools.

The information transmitted through agencies like academic library helps in the all round developments of any social being. The, services offered by the library to the user, creates a learning attitude. The facilities of browsing books through open access system create a feeling of responsibility and also self esteem. Information is highly valuable for social, cultural and economic development of a country; the academic libraries are feeding the information for these developments. The present trend of information needs of a country is to be met out by both academic and public library. However, whatever may be the library but their prime concern is how to serve better ways to the end users.

\section{References}

1. Ashu Shokeen and Sanjay K. Kausrila (2002) Information seeking behaviour of social scientists of Haryana Univ. Library Herald. 40 (1), 28-35.

2. Biswas Subhas C (1985-86) Central secretariat library, user and pattern of use survey. Library Herald. 24, 113143.

3. Francher Beeler MG (1974) Measuring the Quality of Library Services : A Handbook, N.J. Scarecrow.

4. Guide to Government Departmental and other Libraries (1984) British Library Association, London. pp:104.

5. Gupta Anuradha (1973) Users survey of Laxmibai Nagar branch of Delhi Public Library Library Hearld 15(1-2), 47-64.

6. Gupta Anuradha (1987) Quality improvement in library services through users study. In: Quality in Libraries, Seminar papers $32^{\text {nd }}$ All India Library Conf., Anantpur, Jan 3-6: Vashisth CP ed. Indian Library Assoc., 103109.

7. Ikeuchi A (1999) Cost-benefits analysis for public library services. Journal of Information Science [In Japanese] 45 (3), 95-108.

8. Lynden (Frederick C) (1990), Cost analysis of monographs and serials. JASIST 12 (3), 19-40.

9. Spink Amanda et al. (2002), Information seeking and mediated search Part 1. Theoretical framework and research design. J. Am. Soc. for Info. Sci. Technol. (JASIST) 53(9), 695-703.

10. Vijayalaxmi N, Maheswarappa BS (2001) Information use pattern of postgraduate lady students of Gulbarge Univ., Gulbarga. Annals of Library \& Info. Studies. 48(3), 93-106.

11. Wood D N (1969), Discovering the user and his information need. Aslib Proc. 21, 262-270.
Sci. Technol. Edu

CIndian Society for Education and Environment (iSee)
"ICT-driven academic libraries" http://www.indjst.org
Pandian et al. Indian J.Sci.Technol. 